\title{
KAMALA E O CAMINHO DA EMPATIA PARA A ACEITAÇÃO DA ALTERIDADE NOS COMICS
}

\author{
KAMALA AND THE EMPATHIC WAY FOR THE \\ ACCEPTANCE OF THE OTHER IN COMICS
}

\section{KAMALA Y EL CAMINO EMPÁTICO PARA LA ACEPTACIÓN DEL OTRO EN COMICS}

GABRIEL BRAGA FERREIRA DE MELO'

\footnotetext{
${ }^{1}$ Doutorando no programa de Teoria da Literatura e Literatura Comparada da Universidade do Estado do Rio de Janeiro (UERJ). gabrielbfmelo@gmail.com
} 
RESUMO: Não vivemos em bolhas isoladas de onde podemos observar o outro e fingir que ele não está perto quando não o queremos. Mas, com a fragmentação das identidades, qualquer um pode estar na posiçẫo de alteridade dependendo do aspecto a ser analisado. Por esse motivo, é por meio dessa empatia despertada que um caminho para a maior aceitação da alteridade pode ser criado. Por ser o principal expoente dessa nova safra de heróis que retratam a alteridade, Kamala Khan é uma das figuras mais importantes deste século nos comics.

ABSTRACT: We do not live in isolated bubbles from where we can observe the Other and pretend he is not around when we do not want him nearby. Moreover, with the fragmentation of the identities, anyone can be in a position of alterity depending on the aspect to be analyzed. For that reason, it is through the empathy forged in relation to the other that a path of more acceptance of the Other can be created. As the main exponent of the new crop of heroes that depict alterity, Kamala Khan is one of the most important characters in comics of this century.

RESÚMEN: No vivimos en burbujas aisladas donde podemos observar al otro y fingir que no están cerca cuando no nos gustan. Pero, con la fragmentación de las identidades, cualquiera puede estar en una posición de alteridad dependiendo del aspecto analizado. Por eso, a través de una empatía despertada es que se puede crear un camino de más aceptación de la alteridad. Por ser la principal exponente de la nueva cosecha de héroes que representan la alteridad, Kamala Khan es una de los personajes más importantes en los comics de este siglo.

PALA VRAS-CHAVE: Identidade; Deslocamentos; Cultura; Kamala Khan; Comics.

IKEYWORDS: Identity; Displacement; Culture; Kamala Kha; Comics.

PALABRAS CLAVE: Identidad; Desplazamiento; Cultura; Kamala Khan Comics.

$\cos$

Com os inúmeros deslocamentos ocorridos nas últimas décadas, é natural que cada vez mais pessoas sintam-se forasteiras em um grupo, como um elemento que náo se encaixa no ambiente em que se encontram. Esse sentimento náo é algo exatamente novo para muitos fấs de quadrinhos, mesmo antes de tais deslocamentos tornarem-se lugar-comum na nossa vida. O texto escrito por Tom King, na abertura da seção de cartas de sua revista, The Vision, em que esclarece quais histórias ele pretende contar e o porquê, é a explicação perfeita do sentimento compartilhado pelas pessoas que passaram por deslocamentos e também pelos fấs de quadrinhos. The Vision trata do sintozóide Visão e sua família 
(sintozóides criados por ele) tentando viver como uma família normal em Washington. Em seu texto, Tom King escreve:

Quando eu era novo, eu não tinha muito, mas eu tinha os comics. Amigos eram difíceis. Esportes eram difíceis. Escola era difícil. Comics eram fáceis. [...] Se você lia comics, você não era legal. Se as pessoas descobrissem que você lia comics, você náo era legal, a vida se tornava um pouco mais difícil para você.

Então você os escondia. Você escondia sua coleção. Você escondia sua paixão. Você escondia sua "nerdice". O resultado final de tudo isso era alienação, o triste e prolongado sentimento de que aquilo com que você se preocupava, o que realmente importava para você era algo para ser zombado por todos os outros. Você era diferente. Você era esquisito. Você era menos.

Você não era normal. As coisas mudaram. Um pouco. Ainda bem. Mas no fundo, eu acho que os comics ainda são uma mídia dos que não se ajustam. É uma comunidade de forasteiros, um monte de homens e mulheres que, por inúmeros motivos, têm problemas para se ajustar na forma esperada. Pessoas que procuram um escape temporário da boa e dura dor que vem de se chocar contra a fôrma, esperando que ela finalmente quebre.

$[\ldots]$

O que nos leva a contemplar The Vision.

Para mim, o Visão é a chance de explorar a alienação que de vez em quando atrai as pessoas para os comics, a tensão que vem de náo ser normal em uma sociedade que demanda normalidade.

Porque seja lá o que é o Visão, ele não é normal.

Mas como ele tenta ser.

[...]

Esperançosamente, no fim, se eu fizer isso certo, é um conto sobre você e sobre mim.

[...]

Finalmente, aqui no fim, permitam-me retornar um pouco ao início, para a criança e os comics, para o primeiro momento em que percebi que eu não estava sozinho nisso tudo, que a minha "nerdice" era parte de uma "nerdice" maior. Foi lendo a seçâo de cartas, vendo outros escreverem para ela, outros para quem comics também eram fáceis, que eu tive a sensação de que havia uma comunidade lá fora, uma comunidade que poderia pensar que eu era legal, não apesar do fato de eu saber que o Capitão América não era um Vingador original, mas exatamente por saber [...] Por favor, escrevam para cá. Dividam suas histórias. Reclamem das minhas histórias. Eu responderei. Nós conversaremos. E alguma outra criança em algum lugar lerá todas as nossas histórias, saber que ela não está sozinha e perceber que, no fim, o melhor que os comics fazem é deixar que saibamos que todos nós temos nossa própria Visão e que é perfeitamente normal não ser normal. (KING, 2015, tradução nossa). 
Ser considerado esquisito e inferior por gostar de comics. Essa é a história, em maior ou menor grau, da maioria dos fấs de comics. Agora troque comics por qualquer aspecto cultural e a frase continua portando a mesma verdade, apenas cabendo em outro cenário. São essas características que determinam que, mesmo com todas as mudanças, mesmo com a nova popularização dos comics, os quadrinhos ainda sejam uma espécie de literatura marginal. Uma literatura para os forasteiros e os que não se ajustam ao padrão considerado normal, como bem define Tom King. As revistas dos heróis sempre falaram de sujeitos deslocados, só que mais focado no sujeito nerd. Portanto, não é uma completa novidade e tampouco é difícil para os quadrinhos reconhecer os deslocados de um ponto de vista cultural. E é também exatamente essa a razão do porquê de tais heróis serem tão bem recebidos pelo meio dos quadrinhos: a identificação fácil entre semelhantes. O exemplo recente mais icônico talvez seja a jovem Kamala Khan, filha de pais paquistaneses e adepta do Islamismo.

Kamala é uma personagem completamente nova no Universo Marvel, porém a repercussão de sua estreia foi de um tamanho raramente visto em quadrinhos solo de personagens inéditos. Estreando em fevereiro de 2014, a revista conta com idealização da editora Sana Amanat - filha estadunidense de pais paquistaneses que cresceu como uma adepta do Islã nos subúrbios de Nova Jérsei - roteiros de G. Willow Wilson - escritora estadunidense convertida ao Islã - e desenhos de Adrian Alphona. Essa nova versão da Ms. Marvel apresenta Kamala Khan, uma garota estadunidense, filha de paquistaneses, adepta do Islã que vive nos subúrbios de Nova Jérsei e que, após ser exposta a uma névoa, descobre ter desenvolvido poderes de alteração de forma. Nas páginas da revista, vemos como Kamala concilia os diversos aspectos da sua vida e como interage com as pessoas à sua volta, sejam elas adeptas ou não do Islá, estadunidenses ou não.

Por ser uma heroína adepta do Islã em um país onde o ódio aos muçulmanos não é uma mera ficção, houve alguma repercussão negativa e preconceituosa, na mídia em geral, quando do anúncio da heroína cinco meses antes de sua estreia nos quadrinhos. Uma delas foi a de Stephen Colbert (LEHRER, 2013), que, em seu programa - The Colbert Report-, destila comentários preconceituosos contra os comics, o sotaque de uma repórter latina, os 
mulçumanos e o Islamismo. $\mathrm{O}$ apresentador profere, ainda, outras tantas observaçóes sexistas, fala também sobre como uma heroína muçulmana era uma derrota na "guerra cultural" que os Estados Unidos travam e, pior, que ela viria para substituir uma heroína que, segundo ele, "era completamente americana: loira, valores familiares e com dois arredondados músculos peitorais (fazendo um claro gesto de seios com as mãos)”. Stephen arremata dizendo ser uma pena que essas qualidades possuídas pela antiga Ms. Marvel², bem como seu uniforme que mal cobre o corpo da heroína para facilitar a exploração sexual da figura feminina, serão perdidos na versão muçulmana.

Sucesso de vendas, elogiada pela crítica e profundamente amada pelos leitores, a primeira edição de Ms. Marvel foi tudo do que Kamala precisou para acabar com o ódio gerado - ou, pelo menos, silenciá-lo em meio aos inúmeros aplausos, elogios e sinais de adoração recebidos - e se tornar a maior sensação dos quadrinhos desse século até o momento.

Seus números são impressionantes. O site "Legião dos Heróis" (GRAVENA, 2015) informa que a primeira edição da heroína foi reimpressa seis vezes nos Estados Unidos quando, nos dias de hoje, ter uma segunda ou terceira reimpressão já é considerado um sucesso estrondoso. $\mathrm{O}$ site ainda diz que, além das seis reimpressóes, sua revista é também a mais vendida na loja digital da Marvel. Não bastasse isso, a revista da heroína tornou-se, recentemente, o primeiro comics da editora Marvel na história a ganhar o prêmio de "Melhor série" no festival Angoulême, o Cannes dos quadrinhos. Ressalta-se, ainda, que foi o único comics estadunidense premiado no ano de 2016 pelo festival. Mas o que a nova personagem tem que agrada tanto aos leitores?

Kamala Khan é uma jovem de forte identificação com o leitor de quadrinhos. Nerd, é uma fã assumida dos super-heróis - que, enquanto para os leitores são ficcionais, para ela

\footnotetext{
${ }^{2}$ Carol Danvers, a primeira Ms. Marvel - atualmente sob a alcunha de Capitã Marvel - é hoje uma das heroínas mais importantes dos quadrinhos pela relevância que possui no Universo Marvel e pelos temas abordados nas suas histórias - quase sempre de temática feminista. Contudo, desde sua criação na década de 1960 até o fim da primeira década do século XXI, a personagem foi pouco mais do que uma desculpa para desenhar uma mulher e explorar seu corpo que atendia aos padróes de beleza estadunidenses e eram exibidos em um maiô que pouco deixava algo para ser imaginado, sendo a importância da personagem resumida a isso, visto que não fazia parte do grande escalão de heróis como faz hoje.
} 
são da vida real - e até escreve anfics $^{3}$ sobre eles. Na verdade, até a escolha do nome Ms. Marvel como identidade heroica é fruto da sua profunda admiração pela antiga Ms. Marvel, Carol Danvers. Kamala faz pesquisas na internet, quando tem dúvidas, e mostra seu lado completamente fã ao fazer dupla com algum herói. Quando se junta aos Vingadores, dá o grito de guerra da equipe e diz que sempre sonhou em fazer isso. Ela é o leitor de quadrinhos transportado para dentro da revista. A jovem é ainda simpática, um pouco ingênua e divertida. Seus problemas são ter que conciliar sua vida heroica com os estudos, lidar com colegas nem sempre agradáveis no colégio e esconder a verdade dos pais que exigem que ela esteja em casa na hora de dormir e acham que ela está fazendo algo errado, por nem sempre chegar no horário estabelecido. Em todos os aspectos, Kamala Khan é uma pessoa comum, com problemas cotidianos, mas com superpoderes, e suas aventuras são contadas em histórias leves e agradáveis.

A personagem não se rende ao discurso da modernidade que, como define Toro (2010), propunha um discurso universalista e de homogeneização e assimilação do outro, com a perspectiva do centro como um único discurso. Kamala é fruto de um momento das sociedades pós, que oferece a possibilidade do global e também do local como detentor de uma voz com algo a dizer.

É uma nova realidade, uma nova cultura mundial, definida por Hannerz (1995, p.237 apud TORO, 2010, p.10) como marcada pela organização de uma diversidade, ao invés da reprodução da uniformidade. Isto é, um ambiente em que a homogeneização não ocorre e nem nunca terá espaço, justamente pelo tráfego intenso de pessoas e culturas que a globalização e a revolução dos meios de comunicação proporcionam.

Sem correr o risco de ser forçada a se aculturar para ser assimilada pela cultura dominante, Kamala pode experimentar ambas as culturas que exercem influência sobre ela e criar um espaço entre as duas, livre para deslocar significados, dialogar e negociar a sua diferença e sua identificação, seu pertencimento e sua alteridade em relação a cada uma das margens culturais. Kamala habita um entre lugar, como definido por Canclini (2008), em

\footnotetext{
${ }^{3}$ Fanfiction ou fanfic é o termo utilizado para se referir a histórias criadas por fã́s sobre seus personagens preferidos. Distribuídas de forma gratuita em blogs ou fóruns de internet ou pelo preço de custo do material, quando impressas e distribuídas em eventos de quadrinhos.
} 
que a relação da cultura com o território geográfico é perdida, promovendo um choque entre diferentes visões e gerando um sujeito híbrido, mais experimental e tolerante. Ela é a representação da noção desse hibridismo cultural.

Ainda me valendo das palavras de Toro (2010), o professor nos explica que essa terceira cultura não se refere a algo que surge do encontro de uma ou mais culturas, ao contrário, ela é a produção cultural simultânea que se forma do contínuo contato entre culturas. Da mesma forma, a identidade do sujeito que se vê imerso nessa terceira cultura é uma identidade que não é uma mera soma de duas identidades opostas e que se choca constantemente em "um movimento criativo contínuo que segue quebrando o aspecto unitário de cada novo paradigma” (ANZALDÚA, 2005, p.707). Por tudo isso, Kamala é um sujeito que vive imerso em uma cultura híbrida e, como tal, nela "se percebe uma tentativa de redefinir a identidade híbrida não como uma reconciliação do dominante com o subalterno, mas como a mediadora intercultural entre os dois" (SKAR, 2001, p.21-22, tradução nossa).

Em suas histórias, vemos como Kamala é diferente da maioria das pessoas por ter consciência de duas culturas. Sua mãe e seu irmão tentam viver nos Estados Unidos a vida que teriam no Paquistão em cada mínimo detalhe, por isso, sentem como se a vida no país ocidental fosse uma afronta ao que é certo. Kamala, por sua vez, entende que não há como manter uma pureza e, rejeitando também a ideia de ser aculturada e assimilada, cria em si diferentes níveis de cultura islâmica e ocidental. Ela habita uma "zona de contato" que, como define Pratt, é um termo que traz a ideia de uma "co-presença espacial e temporal dos sujeitos anteriormente isolados por disjunturas geográficas e históricas [...] cujas trajetórias agora se cruzam”. (PRATT, 1992 apud HALL, 2009 [2003], p.31), ou seja, um lugar onde a personagem Kamala é produzida pela cultura dominante, mas também acaba por, ativamente, produzir essa mesma cultura.

Ao receber sinais de diferentes culturas, quase sempre conflitantes entre si, a heroína precisa administrar esse choque cultural e encontrar o seu caminho próprio. Valores opostos precisam ser conciliados, negociados. Kamala precisa aprender a ser uma tradutora no sentido de identidades, como define Hall: 
Obrigadas a negociar com as novas culturas em que vivem, sem simplesmente serem assimiladas por elas e sem perder completamente suas identidades. Elas carregam os traços das culturas, das tradiçóes, das linguagens e das histórias particulares pelas quais foram marcadas. A diferença é que elas não são e nunca serão unificadas no velho sentido, porque elas são, irrevogavelmente, o produto de várias histórias e culturas interconectadas, pertencem a uma e, ao mesmo tempo, a várias "casas" (e não a uma "casa" particular). As pessoas pertencentes a essas culturas híbridas têm sido obrigadas a renunciar ao sonho ou à ambição de redescobrir qualquer tipo de pureza cultural "perdida" ou de absolutismo étnico. Elas estão irrevogavelmente traduzidas. A palavra "tradução", observa Salman Rushdie, "vem, etimologicamente, do latim, significando "transferir"; "transportar entre fronteiras". [...] são o produto das novas diásporas criadas pelas migraçôes pós-coloniais. Eles devem aprender a habitar, no mínimo, duas identidades, a falar duas linguagens culturais, a traduzir e a negociar entre elas. As culturas híbridas constituem um dos diversos tipos de identidade distintivamente novos produzidos na era da modernidade tardia. (HALL,2005, p.89)

Vemos essa tradução em ação em momentos em que ela precisa explicar para a mãe o que são fanfics ou para seus amigos se ela pode ou náo sair para uma festa e, como tradutora, precisa entender que o choque entre as diferentes culturas não se dá sem uma luta de poder por detrás de cada conflito.

Kamala sabe que não pode manter uma opinião rígida acerca de tudo, é uma personagem de uma realidade móvel e com o fervor da criação constante em seus relacionamentos. Por intermédio das trocas que efetua com outras identidades - sejam mais fixas ou maleáveis como a dela -, discute, abala, desconstrói e reformula certezas e conformismos próprios e dos outros. De certa forma, Kamala é livre, mas não tem o privilégio de poder parar de se movimentar. A mesma reflexão de Sônia Torres sobre o tema, ao comentar a respeito da obra de Montoya, serve para a heroína quando a teórica afirma ser El Louie "um personagem liminar, epítome da fronteira, do entre-espaço, demonstrando que as zonas culturais fronteiriças estão sempre em movimento, que não são fixas e estáticas”. (TORRES,2001, p.31).

Tal falta de uma forma fixa e estática reflete-se, inclusive, em seus poderes. Kamala é uma alteradora de formas. Ela pode ficar gigante ou minúscula. Pode também transformarse em quem quiser ou no objeto que quiser. Fluida, adaptável, inconstante e aberta a 
mudanças. Seus poderes refletem o modo como ela sempre teve que viver antes mesmo de ganhar características sobre-humanas.

Contudo, tais características culturais não vêm sem um preço. Kamala não possui um lugar em que ela esteja livre desse embate entre culturas e que exigem que ela adote o posto de tradutora, negociadora intercultural, pois já aprendeu que fingir ser o que não é pode ser extremamente danoso. Logo que recebe seus poderes de alterar formas e sem domínio sobre eles, Kamala escuta a voz de Zoe Zimmer, sua frenemy ${ }^{4}$, e, automaticamente, transforma-se na figura de Carol Danvers, a heroína 100\% estadunidense definida por Kamala como loira, poderosa e sem todo o conflito cultural que essa carrega. Assim que essa transformação acontece, a nova Ms. Marvel percebe que, sempre que escuta a voz da amiga, tem a necessidade de parecer alguém melhor aos olhos de Zoe e que se adeque ao que essa considera normal, mas, no fim, acaba por se sentir pequena e insignificante. Nesse momento, como reflexo do processo de compreensão, seus poderes a fazem diminuir e ficar do tamanho de um inseto.

A partir dessa experiência, Kamala começa a tomar uma consciência crítica acerca de seus sentimentos e as relaçóes de harmonia e combate que são estabelecidas em contatos interpessoais no seu dia a dia e das quais não pode fugir. Said já alertava para esse problema quando afirmava que "o hábito da dissimulação é cansativo e desgastante. O exílio jamais se configura como o estado de estar satisfeito, plácido ou seguro" (SAID, 2003, p.60) e Kamala chega ao mesmo entendimento por meio de seus poderes.

E essa é a nova Ms. Marvel. Uma super-heroína que, diferente de muitos outros heróis, tem a luta mais difícil quando não está com o uniforme enfrentando o candidato do mês a dominador do mundo: o de viver entre duas culturas, das quais ela nunca poderá pertencer por inteiro. Uma luta que nunca chega a um resultado final. Uma personagem que entende exatamente o que Bauman quer comunicar quando escreve que:

Estar total ou parcialmente "deslocado" em toda parte, não estar totalmente em lugar algum (ou seja, sem restriçóes e embargos, sem que

\footnotetext{
4 Termo criado em inglês da junção das palavras "friend" e "enemy", isto é “amigo" e "inimigo". Refere-se ao tipo de amigo que, com suas açóes e palavras, acaba colocando o outro para baixo (intencionalmente ou náo).
} 
alguns aspectos da pessoa "se sobressaiam" e sejam vistos por outras como estranhos), pode ser uma experiência desconfortável, por vezes perturbadora. Sempre há alguma coisa a explicar, desculpar, esconder ou, pelo contrário, ressaltadas e tornadas mais claras. As "identidades" flutuam no ar, algumas de nossa própria escolha, mas outras infladas e lançadas pelas pessoas em nossa volta, e é preciso estar em alerta constante para defender as primeiras em relação às últimas. Há uma ampla probabilidade de desentendimento, e o resultado da negociaçáo permanece eternamente pendente. (BAUMAN, 2005, p.19)

Portanto, essa jovem heroína de 16 anos tem os mesmos problemas de seus leitores, de se adequar à norma. Apenas que os problemas dela têm uma origem não exatamente compartilhada por todos os seus făs: ela é a filha que nasceu nos Estados Unidos de pais paquistaneses da cidade de Karachi. O que a coloca em eterno conflito da sua porção estadunidense com seus pais de cultura muçulmana e da sua porção muçulmana com seus amigos de cultura ocidental. Porém, esse sentir-se em constante embate com pessoas que não a entendem, tanto dentro quanto fora do lar, é mais um sentimento com o qual os leitores de comics conseguem se relacionar com Kamala.

Com todo esse poder em suas mãos - e não me refiro aos seus superpoderes, mas o de ser relacionável e criar uma empatia com os leitores -, Kamala tornou-se uma importante ferramenta na luta contra o preconceito nos Estados Unidos. Em tempos nos quais uma ala forma opiniōes na sociedade em direção a um sentimento anti-islâmico e até de guerra ao Islá, a personagem dos quadrinhos, com todo o seu alcance, nos apresenta o outro lado, o lado de quem é o odiado nesse sentimento, o lado de quem receberá a bala da guerra.

Kamala informa a todos que sua cultura não a faz tão diferente assim do jovem nãoislâmico, que a religião dela não a torna incapaz de sentir as mesmas emoçóes e ter que enfrentar as mesmas dificuldades que o estadunidense mainstream enfrenta, muito pelo contrário, que ela tem os mesmos problemas. Em suas revistas, o foco das histórias está nos problemas surgidos nas relaçóes interpessoais de amizade e amor da personagem e também naqueles que aparecem para alguém que está deslocado, que é o diferente onde quer que esteja. Kamala mostra um contraponto à política de ódio e uma opção contra o preconceito. 
Porém, a heroína não apresenta apenas uma discussão com a cultura estadunidense, ela também se coloca em constante conflito com a cultura de seus pais. Kamala é um sujeito híbrido. Não pode viver apenas na margem paquistanesa ou na estadunidense. Ela vive no meio das duas, não como uma composição resultante de duas culturas, mas como um ser traduzido. Em Kamala, o Islã e o ocidente se encontram e, em um constante diálogo, começam o debate que o mundo real tanto precisa. Nas palavras de Rula Jebreal, uma jornalista palestino-italiana premiada e analista de política estrangeira da MSNBC:

Kamala me faz lembrar de mim mesma quando eu tinha 14 anos, testemunhando violência no Oriente Médio. Eu perguntei ao meu pai porque a violência era justificada no Islã e a resposta dele foi que o perigo não estava no livro sagrado, o Corão, mas nos cérebros que interpretam ele. Hoje, o perigo não está com os muçulmanos, mas nos cérebros (ou falta deles) que interpretam o Islã e a escritura muçulmana para o mundo moderno. Estas são as pessoas que evitam que os jovens muçulmanos respirem livremente sem medo de serem julgados pelos seus companheiros estadunidenses. O trabalho da Marvel é um divisor de águas para acabar com o medo e a ignorância e criar uma maior consciência e familiaridade. (JEBREAL, 2013, tradução nossa).

Em meio a tantos heróis que levantam as bandeiras de suas causas, a nova Ms. Marvel faz isso sem precisar ir para uma guerra - retratável até pelo fato de seu primeiro arco de histórias não possuir um vilão para enfrentar. Ainda assim, Kamala é, talvez, junto da Capitã Marvel e do novo Capitão América, a revista mais importante e de maior influência da Marvel no mundo real.

Grande parte do acerto vem também do fato de a Marvel deixar a heroína nas mãos da competente G. Willow Wilson, uma estadunidense convertida ao Islamismo que, além de escrever quadrinhos e livros, é ensaísta e jornalista focada na literatura árabe e sob o comando da editora Sana Amanat, uma estadunidense que cresceu na realidade de ser uma muçulmana nos Estados Unidos. Ou seja, em maior ou menor grau, duas Kamalas do mundo real. Ambas souberam criar um quadrinho que, como elas mesmas definem, não visa converter ninguém, mas retrata como essa parte importante da vida da Kamala afeta o seu dia a dia como heroína e como pessoa comum. A nova revista da Ms. Marvel traz o tipo de obra em que vemos o sujeito reproduzido nela ser exatamente o sujeito que a produz. 
Embora este artigo tenha como foco a personagem Kamala, no universo das HQs, ela não é a única personagem merecedora dos holofotes quando o assunto é o sujeito deslocado e o choque entre culturas. Personagens como Blindspot, chinês ilegal coprotagonista das histórias do Demolidor; Amadeus Cho, o coreano-americano que se transformou no novo Hulk; e o latino e negro Miles Morales, que assumiu o uniforme de Homem-Aranha e, mais do que um sucessor de Peter Parker, tornou-se uma personalidade própria e original são alguns dos nomes que nos mostram em suas revistas o retrato exposto por Yúdice de que, assim como são esses personagens, os "imigrantes raciais são contribuintes explorados na economia cultural; eles 'dão vida' a uma cidade, como Castells argumenta, não apenas através de seus trabalhos nas indústrias de serviço, mas também no seu impacto cultural”. (YÚDICE, 2003, p.7-8, tradução nossa). Heróis como Red Wolf, personagem principal de um comic sobre um índio nativo estadunidense transportado para os dias de hoje e que tem como desenhista Jeffrey Veregge, um artista de igual origem, também merecem uma atenção, pois, tal qual os imigrantes, os nativos estadunidenses veem-se rejeitados pela cultura dominante dado seu caráter intraduzível. Blindspot, inclusive, é responsável por um momento forte na revista Daredevil \#2 quando fala sobre a experiência dele como ilegal em um país que lhe nega qualquer direito, apesar de suas muitas contribuiçóes diárias. Sobre isso o herói declara:

Você disse que me ajudaria e aí disse que deveríamos deixar o advogado cuidar disso. Essa deveria ter sido minha primeira dica. Advogados não ajudam pessoas como eu. [...] Ninguém nos ajuda. Esse é o problema. É por isso que eu estou fazendo tudo isso. Nós lavamos suas louças, nós entregamos seus jantares... Nós somos uma parte muito maior de suas vidas do que vocês querem admitir. Mas nós somos ilegais, então quem se importa? (SOULE, 2015, s.p, grifos do autor, tradução nossa)

Salmon Rushdie (1991) definiu que parte do assunto da literatura é encontrar novos ângulos para entrarmos na realidade e que a distância e a perspectiva geográfica de quem vem de longe pode oferecer tais ângulos. E é exatamente essa nova visão que Kamala, Blindspot e os outros heróis desenraizados nos oferecem. Aproveitando-se dessa experiência forçada de ser o diferente, o deslocado, esses novos heróis são capazes de "não mais 
confundir o real com o ideal, nem a cultura com a natureza: não é porque os indivíduos se conduzem de forma diferente que deixam de ser humanos" (RUSHDIE, 1991, p.27).

Com essa lição de maior tolerância, esses personagens nos trazem mais perto da civilização aprofundada que nos desenha Todorov (2010) em que pessoas com culturas, costumes e sociedades organizadas de modo diferente dos nossos serão aceitas tão humanas como nós. Uma civilização em que ter uma cultura não significará um confinamento eterno. Tais personagens também são capazes de, a partir de sua situação de desenraizados, confundir, desconcertar e, por fim, deslocar o sujeito da cultura dominante, recrutando esses para seu lado da luta, para sua "visão de desligamento com relação ao que vem naturalmente através da interrogação e do espanto”. (RUSHDIE, 1991, p.27).

Alguns passos em direção a essa maior tolerância já existem. Um caso exemplar é o evento ocorrido que teve como figura central a personagem Kamala em que esta mostrou o quão poderosa ela pode ser também no nosso mundo e não apenas nos comics mensais, como reporta a matéria de inúmeros jornais, incluindo o Daily Dot (ROMANO, 2015).

Em 2015, em São Francisco, o American Freedom Defense Initiative, um grupo que declara ter como objetivo parar a islamização dos Estados Unidos, colou inúmeros outdoors preconceituosos em que, ironicamente, pedia o fim do ódio espalhado pelos muçulmanos. Nesses cartazes, a mensagem pregada era a de um boicote aos países islâmicos, associando a imagem do povo islâmico a Hitler e dizendo que o Corão prega ódio aos judeus, como vemos abaixo. 
Figura 1: Outdoor original

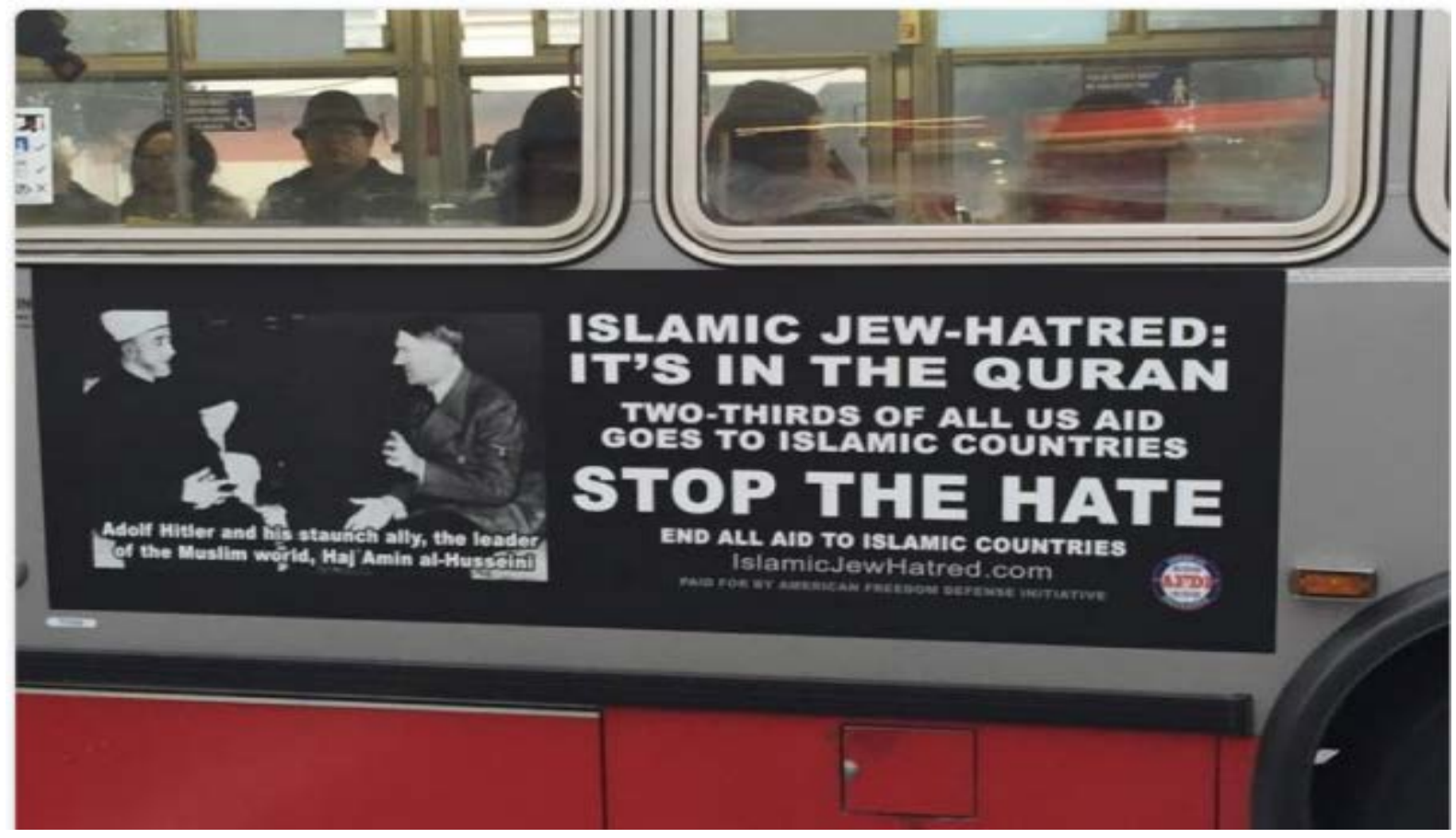

Fonte: http://www.dailydot.com/geek/kamala-khan-graffiti-anti-islamic-bus-ad

Como resposta, artistas de rua, sem qualquer associação com a editora Marvel, promoveram uma modificação dos cartazes valendo-se exatamente da figura da nova Ms. Marvel, uma heroína que, na época, não possuía nem um ano inteiro de existência. Nas novas versóes, viam-se mensagens pedindo o verdadeiro fim do ódio, do racismo e dos "panacas fundamentalistas" que pregam o ódio sob a desculpa de liberdade de expressão, como vemos nas figuras abaixo: 
Figura 2: Outdoor remodelados.

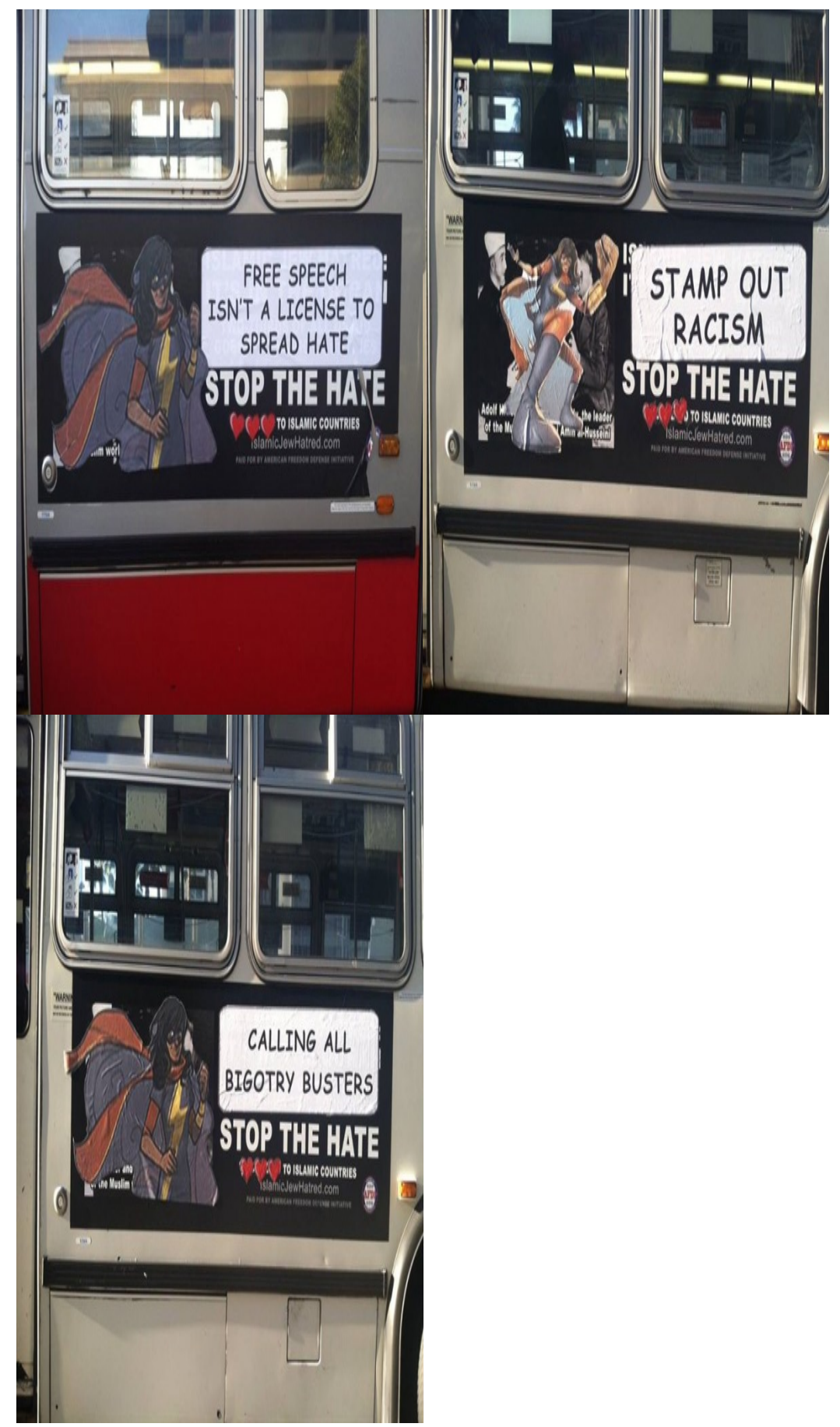

Fonte: http://www.dailydot.com/geek/kamala-khan-graffiti-anti-islamic-bus-ad 
Esse desempenho da heroína muçulmana, que extrapola o fandom ${ }^{5}$ e ganha a luta nas ruas, como vimos em São Francisco, dá ainda mais esperança de que os comics estão afetando a sociedade e levando-a em direção a uma aceitação cada vez maior do outro culturalmente diferente. Resistência ainda existe, o preconceito ainda é grande, mas esses super-heróis mostram que são capazes de, mostrando a sua hibridez, sua mestiçagem, a vida daquele que não habita margens, mas o espaço entre elas, nos conscientizar, nos deslocar e nos tornar mais compreensíveis com o diferente. Finalmente, como constata Stuart Hall:

Como observou certa vez o romancista Salman Rushdie, "o hibridismo, a impureza, a mistura, a transformação que vem de novas e inusitadas combinaçóes dos seres humanos, culturas, ideias, políticas, filmes, cançôes" é "como a novidade entra no mundo". Não se quer sugerir aqui que, numa formação sincrética, os elementos diferentes estabelecem uma relaçáo de igualdade uns com os outros. Estes sáo sempre inscritos diferentemente pelas relaçóes de poder - sobretudo as relaçóes de dependência e subordinação sustentadas pelo próprio colonialismo. (HALL, 2009 [2003], p.34):

Kamala e os outros novos heróis são a novidade nos quadrinhos. Há décadas os comics precisavam da vitalidade e inovação que eles trouxeram, ainda que não soubessem disso até eles chegarem. Tais personagens são capazes de nos deslocar e abrir nossos olhos para uma visão sob o prisma da alteridade através da nossa identificação com eles e consequente empatia que se desperta.

Com sorte, por meio desses heróis que possuem marcas que os identificam como um Outro, suas aventuras e a empatia que eles nos despertam, uma nova forma de pensar entrará no mundo real. Uma forma de pensar em que o Outro, o diferente, seja aceito e compreendido não como um inferior ou um superior, não como uma ameaça, mas como um humano como tantos outros em uma sociedade multicultural de fato e não somente em discursos. Eventos como o ocorrido em São Francisco, com o uso tão aberto de um personagem de quadrinhos para uma mensagem tấo clara e direta contra a intolerância e o

\footnotetext{
${ }^{5} \mathrm{O}$ termo refere-se a um grupo de pessoas que compartilham o mesmo interesse sobre um determinado assunto e gastam muito de seu tempo em atividades relacionadas ao tema de seu interesse. Geralmente usado para referir-se às fẫs de determinados produtos da cultura popular.
} 
preconceito, são capazes de nos tornar otimistas quanto à possibilidade de esses heróis serem capazes de auxiliar na melhoria não apenas do mundo ficcional, mas também na do nosso mundo real. 


\section{REFERÊNCIAS}

ANZALDÚA, Gloria. La conciencia de la mestiza: rumo a uma nova consciência. Revista Estudos Feministas. Florianópolis: UFSC, 13(3): 704-719, setembro-dezembro/2005.

BAUMAN, Zygmunt. Identidade. Trad. Carlos Alberto Medeiros. Rio de Janeiro: Zahar, 2005.

CANCLINI, Nestor García. Culturas híbridas. Trad de Ana Regina Lessa et al. $4^{\mathrm{a}}$ ed, $4^{\mathrm{a}}$ reimp. São Paulo: Edusp, 2008

GRAVENA, Leo. 10 motivos para Ms. Marvel ser o "novo Homem-Aranha"! Legiāo dos Heróis, 2015. Disponível em: <http://legiaodosherois.uol.com.br/lista/10-motivos-params-marvel-ser-o-novo-homem-aranha.html/7>. Acesso em: 06 de fevereiro de 2016.

HALL, Stuart. A identidade cultural na pós-modernidade. Trad. de Tomaz Tadeu da Silva e Guacira Lopes Louro, 10 ed. Rio de Janeiro: DP\&A, 2005.

HALL, Stuart. Da diáspora. Identidades e Mediaçôes Culturais. Org. Liv Sovik. Trad. Adelaide La Guardia Resende et alii. Belo Horizonte: Editora UFMG, 2009 [2003].

JEBREAL, Rula. Meet the Muslim Ms. Marvel: Kamala Khan's Fight Against Stereotypes. The Daily Beast, $2013 . \quad$ Disponível em: <http://www.thedailybeast.com/articles/2013/11/08/meet-the-muslim-ms-marvel-kamalakhan-s-fight-against-stereotypes.html>. Acesso em 12 de fevereiro de 2016.

KING, Tom; WALTA, Gabriel. Vision (2015 -) \#2. New York: Marvel Comics, 2015.

LEHRER, Brian. Ms. Marvel's Reboot. The Colbert Report, 2013. Disponível em: $<$ http://www.cc.com/video-clips/rpo0ya/the-colbert-report-ms--marvel-s-reboot>. Acesso em 11 de fevereiro de 2016.

ROMANO, Aja. San Francisco activists fight Islamophobic ads with art of Muslim superhero Kamala Khan. The Daily Dot, 27 de janeiro de 2015. Disponível em: <http://www.dailydot.com/geek/kamala-khan-graffiti-anti-islamic-bus-ad/>. Acesso em 12 de fevereiro de 2016.

RUSHDIE, Salman. Imaginary Homelands: Essays and Criticism. London: Granta, 1991.

SAID, Edward. Reflexóes sobre o exílio e outros ensaios. Rio de Janeiro: Companhia das Letras, 2003. 
SKAR, Stacey Alba D. Voces hibridas. La literatura de chicanas y latinas en Estados Unidos. Santiago: RIL Editores, 2001.

SOULE, Charles; GARNEY, Ron. Daredevil (2015 -) \#2. New York: Marvel Comics, 2015.

TODOROV, Tzvetan. O medo dos bárbaros. Para além do choque das civilizaçóes. Rio de Janeiro: Vozes, 2010.

TORO, Fernando de. El desplazamiento de la literatura, la literatura del desplazamiento y la problemática de la identidad. Extravio. Revista electrónica de literatura comparada, núm.5. Universitat de València, 2010. Disponível em: <http://www.uv.es/extravio>. Acesso em: 05/08/2012.

TORRES, Sonia. Nosotros in USA. Literatura, etnografia e geografias de resistências. Jorge Zahar Ed. Rio de Janeiro, 2001.

YÚDICE, George. "Introduction". In: The Expediency of Culture: Uses of Culture in the Global Era. Durham, NC: Duke UP, 2003. 